\title{
STATE LIABILITY FOR FINAL COURT ORDERS SOUNDING IN MONEY: AT LONG LAST ALIGNMENT WITH THE CONSTITUTION
}

\author{
Nic JJ Olivier \\ BA MA LLB LLD LLD BA(Hon) BPhil \\ Professor, SADC Centre for Land-related, \\ Regional and Development Law and Policy \\ University of Pretoria \\ Clara Williams \\ LLB \\ Extraordinary Lecturer, Faculty of Law \\ University of Pretoria \\ Non-practising Attorney
}

\section{SUMMARY}

Since the commencement of the State Liability Act 20 of 1957 the (until 2011) prevailing legislation rendered it almost impossible to satisfy judgment debts sounding in money against the State. There has been a continuous struggle in South Africa "to reach a balance between State immunity from tort liability and government accountability to the State's citizens". The State Liability Amendment Act of 2011 (following on the Constitutional Court's decision in Nyathi v MEC for Department of Health Gauteng 20085 SA 94 (CC)) will enable judgment creditors to obtain effective relief against the State.

\section{INTRODUCTION}

Since the commencement of the State Liability Act 20 of 1957 the (until now) prevailing legislation rendered it almost impossible to satisfy judgment debts sounding in money against the State. There has been a continuous struggle in South Africa" "to reach a balance between State immunity from tort liability and government accountability to the State's citizens". ${ }^{2}$ Dingaan Hendrik

And in other jurisdictions.

Nyathi v MEC for Department of Health Gauteng 20085 SA 94 (CC) (hereinafter "2008 CC case") par 89. 
Nyathi's application for monetary relief against the State finally ended in the Constitutional Court. As a result, it is envisaged that new legislation will soon commence in order to enable judgment creditors to obtain effective relief against the State.

This article provides an overview of the State Liability Act 20 of 1957 and of Nyathi's claim against the State. A discussion of the 2005 High Court case (regarding, amongst others, the constitutional invalidity of section 3 of the State Liability Act 20 of 1957), is followed by an examination of the subsequent 2008 CC case. The provisions of the Constitution Eighteenth Amendment Bill, 2009 and the State Liability Bill, 2009, are set out (as well as an explanation regarding the reasons why the authors are of the view that these were an unconstitutional attempt to address the matter at hand). A brief overview of the post-2008 cases and the courts' interpretation of the 2008 Constitutional Court case are provided. The authors provide a detailed summary of the 2010 Constitutional Court case, and conclude with an indepth overview of the 2011 State Liability Amendment Bill as well as a number of recommendations.

\section{OVERVIEW OF STATE LIABILITY ACT 20 OF 1957}

The State Liability Act 20 of 1957 (hereinafter "the Act") was assented to on 26 March 1957 and commenced on 5 April 1957. The Act repealed its predecessor, the Crown Liabilities Act 1 of $1910,{ }^{3}$ and provides for certain claims against the State to be cognizable by a court, as well as the citing of a Minister as a nominal defendant or respondent. Section 3 of the Act states as follows:

"No execution, attachment or like process shall be issued against the defendant or respondent in any such action or proceedings or against any property of the State, but the amount, if any, which may be required to satisfy any judgment or order given or made against the nominal defendant or respondent in any such action or proceedings may be paid out of the National Revenue Fund or a Provincial Revenue Fund, as the case may be".

3 In Nyathi v Member of the Executive Council for the Department of Health, Gauteng and the Minister of Justice and Constitutional Development, Case No. 26014/2005, the court referred to Schierhout v Minister of Justice 1926 AD 99 as quoted in Nv Government of the Republic of South Africa (No 3) 20066 SA 575 (D\&CLD), where it was stated that the "Legislature was content to rely upon the moral obligation which the decree of a court was bound to exert. No process of any kind was to be exercised as against the Crown representatives or Crown property" (par 10). In par 11, the High Court also stated that "it has also expressly been held that, despite slight differences in the wording of the relevant sections of the aforesaid two Acts, the effects of the provisions are the same". In this regard, see also par 16-18 of the 2008 CC case, in which the court stated that: "[t]he section relating to the attachment of the assets of the State is fundamentally similar to the impugned section in the State Liability Act. The High Court found the two pieces of legislation to be so similar that the case law in relation to the one applied to the other, and this conclusion cannot be doubted", that the Crown Liabilities Act 1 of 1910 "was in line and compatible with the doctrine of parliamentary supremacy", and that the State was placed above the law, and, accordingly, the State could not be held accountable for its actions. 
Before Dingaan Hendrik Nyathi (hereinafter "Nyathi") approached the High Court for monetary relief, various provisions of the Act received the attention of the courts. ${ }^{4}$

\section{DINGAAN HENDRIK NYATHI'S CLAIM AGAINST THE STATE}

In August 2002, Nyathi sustained $30 \% 2^{\text {nd }}$ and $3^{\text {rd }}$ degree burn wounds after a paraffin stove was thrown at him. Subsequent to his admission to the Pretoria Academic Hospital, a central venous line was incorrectly inserted into his right carotis communis artery. He was transferred to Kalafong Hospital the next day, where hospital staff failed to diagnose said incorrect insertion timeously. Nyathi consequently suffered a stroke and severe left hemiplegia as a result of the incorrect insertion, as well as the subsequent omissions by the medical staff of both hospitals. Nyathi was totally and permanently disabled, and, as a result, was completely dependent on his wife, a pizza baker, ${ }^{5}$ and in need of full-time care and medical treatment. Nyathi and his wife had four minor children. Not surprisingly, the Nyathi family was unable to provide for their daily living expenses and Nyathi's medical and legal expenses. ${ }^{6}$

In July 2005, almost three years after his admittance to the Pretoria Academic Hospital, Nyathi instituted action against the MEC for the Department of Health, Gauteng (hereinafter the "MEC"), and claimed damages totalling R1 496000,00 for the past, present and future sequelae of his severe left hemiplegia as a result of the "improper medical care and treatment administered to him". The MEC eventually conceded the merits of

4 See, eg, Chagi v Special Investigating Unit 20092 SA 1 (CC); Dumasi v Commissioner, Venda Police 19901 SA 1068 (V); East London Western Districts Farmers' Association v Minister of Education and Development Aid 19892 SA 63 (A); Golden Arrow Bus Services (Pty) Ltd v Minister of Transport 20095 SA 322 (C); Hako v Minister of Safety and Security 19962 SA 891 (TkS); Hwedhanga $v$ Cabinet for the Territory of South West Africa 1988 (2) SA 746 (SWA); Inkatha Freedom Party $v$ Truth and Reconciliation Commission 20003 SA 119 (C); Jayiya v Member of the Executive Council for Welfare, Eastern Cape 20042 SA 611 (SCA); Kate v MEC for the Department of Welfare, Eastern Cape 20051 SA 141 (SE); Lombard v Minister van Verdediging 20023 SA 242 (T); Maharaj Brothers v Pieterse Bros Construction (Pty) Ltd 19612 SA 232 (N); Masuku v Mdlalose 19981 SA 1 (SCA); Mateis v Ngwathe Plaaslike Munisipaliteit 20034 SA 361 (SCA); Matiso v Minister of Defence 20056 SA 267 (TkD); Mhlongo NO v Minister of Police 19782 SA 551 (A); Minister of Home Affairs v American Ninja IV Partnership 19931 SA 257 (A); Minister of Law and Order $v$ Patterson 19842 SA 739 (A); Mjeni v Minister of Health and Welfare, Eastern Cape 20004 SA 446 (TkH); Moodley v Umzinto North Town Board 19982 SA 188 (SCA); Naidoo v Minister van Polisie 19764 SA 954 (T); Shoba v Officer Commanding, Temporary Police Camp, Wagendrift Dam; Maphanga v Officer Commanding, South African Police Murder and Robbery Unit, Pietermaritzburg 19954 SA 1 (A); Western Cape Housing Development Board v Parker 20033 SA 168 (C); Yellow Star Properties 1020 (Pty) Ltd v MEC, Department of Development Planning and Local Government, Gauteng 20093 SA 577 (SCA); and York Timbers Ltd v Minister of Water Affairs and Forestry 20034 SA 477 (T).

5 Who, at the time of the High Court case earned a mere R1 400,00 plus R200,00 overtime per month. In addition to this, Nyathi received a social grant of R570,00 per month.

6 Nyathi $v$ Member of the Executive Council for the Department of Health, Gauteng and the Minister of Justice and Constitutional Development, Case No. 26014/2005 (hereinafter "HC case") par 2.1-2.6; and the 2008 CC case par 7-8. 
the action, and the quantum portion was set down for hearing in May 2007 (nearly five years after the paraffin incident).

While awaiting the hearing date, Nyathi's health deteriorated. He was in serious need of interim treatment and medication. In addition, Nyathi did not have the means to secure medical experts, counsel and his attorney. His attorney contacted the State Attorney representing the MEC (hereinafter "the State Attorney") in July 2006, requesting an interim payment of R317 700,00 (and stated that the court would be approached if payment was not made). After a number of telephonic discussions, the State Attorney indicated on 23 August 2006 that the MEC was willing to make a lump sum payment of R500 000,00 as full and final settlement. Nyathi rejected the settlement proposal, and the MEC was given until 25 August 2006 to respond. No response was forthcoming, and Nyathi lodged an application in terms of Rule 34A during September 2006. The application came before the then Transvaal Provincial Division (hereinafter "the TPD") on 22 November 2006. The MEC again did not respond, and Mabuse AJ made an order that interim payment of R317 700,00 be made. In addition, the judge also made a costs order against the MEC. A copy of the order was sent to the State Attorney, as well as a letter requesting payment within 30 days, failing which the court would again be approached for an order to compel. No payment was received, and Nyathi lodged a further application with the TPD (hereinafter "the Nyathi HC case"). ${ }^{8}$ It was clear from Nyathi's inability to obtain payment from the MEC, that the current legislation had a lacuna as court orders sounding in money against the State could not readily be enforced.

NYATHI V MEMBER OF THE EXECUTIVE COUNCIL FOR THE DEPARTMENT OF HEALTH, GAUTENG AND THE MINISTER OF JUSTICE AND CONSTITUTIONAL DEVELOPMENT, CASE NO. 26014/2005APPLICATION FOR AN ORDER DECLARING SECTION 3 OF THE STATE LIABILITY ACT 20 OF 1957 INCONSISTENT WITH THE CONSTITUTION

\section{Background, parties and the hearing in the unopposed motion court}

On 21 February 2007 Nyathi applied to the TPD for an order declaring section 3 of Act unconstitutional. ${ }^{9}$ The Minister of Justice and Constitutional Development (hereinafter "the Minister"), as the national executive authority responsible for the administration of the Act, was also joined in the case. Nyathi sought an order (a) declaring section 3 of the Act unconstitutional;

HC case par 2.7 and 2.9-2.10; and the 2008 CC case par 9.

$8 \mathrm{HC}$ case par 2.11, 2.13-2.17 and 3.1; and the $2008 \mathrm{CC}$ case par 10-15. According to the 2008 CC case (par 13), the State Attorney advised Nyathi's attorneys on 30 August 2006 that the MEC was taking issue with paying the amount as in interim payment. The State Attorney indicated that the MEC did not dispute that it might in future be liable for payment, but requested that payment be deferred until the trial court had decided the issue of costs.

9 Nyathi v Member of the Executive Council for the Department of Health, Gauteng and the Minister of Justice and Constitutional Development, Case No. 26014/2005. See also the 2008 CC case par 19-24 for a summary of the HC case. 
(b) compelling the MEC to comply with the court order within three days of said order (failing which Nyathi would apply for an order declaring the MEC to be in contempt of court, and committing the MEC to gaol for 90 days) $;{ }^{10}$ and (c) an order as to costs. The court was requested to hear the matter as one of urgency. The date of the hearing was 27 March 2007. The MEC and the Minister (hereinafter "the respondents") failed to file a notice or an answering affidavit. A notice in terms of Rule $16 \mathrm{~A}$ was delivered to the Registrar, and was displayed on a notice board in court, but also did not elicit a response. The application was enrolled on the unopposed motion roll, and the court "was satisfied that a sufficient degree of urgency existed, meriting the limited non-compliance with the Rules". It was clear to the court that the respondents, represented by the State Attorney, had the necessary knowledge of the application. A letter dated 12 March 2007 was received by Nyathi's attorney from the State Attorney indicating that payment would be effected within 14 days of said letter, and requesting that the application be postponed. No payment was made by the time the hearing took place (which was more than 14 days after the letter of the State Attorney was received). The respondents and the State Attorney did not appear at the hearing. ${ }^{11}$ The court delivered its judgment on 30 March 2007.

\section{The High Court's discussion of section 3 of the Act}

It is clear that judgment creditors can easily enforce compliance with court orders if the defendant is a party other than the State. A distinction can be made between (a) orders ad factum praestandium; ${ }^{12}$ and (b) orders ad pecuniam solvendam. ${ }^{13}$ However, section 3 of the Act, amongst others, prohibits the execution of State assets: "No execution, attachment or like process shall be issued against a defendant or a respondent in any such action or proceedings or against the property of the State". The State is morally obliged to honour court orders - this obligation with regard to public administration has become entrenched in section 195 of the Constitution of the Republic of South Africa, 1996 (hereinafter the "Constitution"). ${ }^{14}$

The court considered various previous court cases, and came to the conclusion that the State and its officials very often fail to (a) honour their constitutional and moral obligations; and (b) comply with court orders. ${ }^{15}$

10 Nyathi did not proceed with his prayer relating to an order of contempt of court and committal to gaol (as such committal is precluded; both could only properly be considered after the Constitutional Court had confirmed the finding of unconstitutionality. The proper remedy would be the issuing of writ of execution and attachment and sale of assets).

11 HC case par 3.2-3.9.

12 The judgment creditor can apply for an order of contempt of court by, and committal of, the defaulting debtor.

13 The judgment creditor can apply for the issuing of a writ of execution, which will lead to the attachment of assets and the sale thereof. This process is followed if the payment is one sounding in money, and would in Nyathi's case be the appropriate process if the State was not the opposing party. $\mathrm{HC}$ case par 4-5 and 7 .

14 S 195 sets out the basic values and principles governing public administration.

15 The court stated that reasons could include pure negligence, incompetence or laziness. HC case par 11-12. 
The following sections of the Constitution were also relevant to the case:

1 Section 34: Nyathi's right of access to courts was prejudiced by the fact that he was prevented from properly preparing for the quantum portion of the trial; ${ }^{16}$

2 section 165(5): This subsection states that "an order or decision issued by a court binds all persons to whom and organs of state to which it applies"; and

3 section 195(1)(f): According to this subsection, public administration must be accountable.

The court made it clear that section 3 of the Act "is inconsistent with the aforesaid constitutional provisions by placing the state and its officials above the law and beyond the very orders which should bind it or hold it accountable". ${ }^{18}$ The court also considered other cases that support its statement.

With reference to case law, the court made it clear that neither reading down, reading in nor excision of a portion thereof could be utilized with regard to section 3 of the Act. The court indicated that a finding of unconstitutionality is only effective after confirmation by the Constitutional Court (hereinafter "the CC"), and stated that it was of the opinion that Nyathi would be entitled to his order "if only to enforce the rule of law and obtain confirmation of the supremacy of the Constitution". ${ }^{20}$ The court went on to consider whether a declaration of invalidity having immediate effect would disrupt good governance and stated as follows:

"Any levying of execution or attachment of assets of the State as a result of the striking down of the prohibition contained in Section 3 of the State Liability Act, could only come about as a result of the State's failure to comply with a court order and such good governance imperatives as in any event constitutionally enshrined. Any disruption, or rather, the prevention thereof will therefore be in the hands of the State itself and that of its officials. For this reason, I do not consider an order suspending the declaration of invalidity for any period and on any conditions necessary."

\section{The HC order}

The High Court made the following order:

1 The following portion of section 3 of the Act was declared to be inconsistent with the Constitution and invalid: "No execution, attachment or like process shall be issued against a defendant or a respondent in

16 The consequent right to have the effects of successful access to courts implemented is also prejudiced. HC case par 19. With regard to Nyathi's financial situation, see the discussion above (par 3).

17 The court stated that reasons could include pure negligence, incompetence or laziness. HC case par 13-15.

$18 \mathrm{HC}$ case par 16 and 23

19 HC case par 17-18.

20 HC case par 24-27.

21 HC case par 28. 
any such action or proceedings or against the property of the State, [but]";

2 a costs order against the MEC on attorney-client scale, including the costs of two counsel; and

3 the Registrar was ordered to lodge a copy of the judgment as soon as practically possible with the Registrar of the CC. ${ }^{22}$

5 NYATHI $V$ MEC FOR DEPARTMENT OF HEALTH
GAUTENG 20085 SA 94 (CC) - APPLICATION FOR
CONFIRMATION OF ORDER DECLARING SECTION
3 OF THE STATE LIABILITY ACT 20 OF 1957
INCONSISTENT WITH THE CONSTITUTION

\section{Parties}

Nyathi passed away on 4 July 2007, prior to the finalization of the first CC case in 2008. The matter was set down for hearing on 4 May 2007, and after the $\mathrm{CC}$ engaged with counsel regarding the non-payment of the interim order, the interim payment was made on the same day. The State Attorney "was directed to furnish an explanation for the tardiness of her department in complying with the High Court order". The 2008 CC case was set down for hearing on 30 August 2007. ${ }^{23}$ Nyathi's wife (hereinafter "the applicant") substituted Nyathi as the applicant. The respondents of the HC case were the respondents of the first CC case, and were again represented by the State Attorney. The Centre for Constitutional Rights (hereinafter "the CFCR") was admitted as amicus curiae. ${ }^{24}$

\section{Submissions by the applicant, respondents and amicus curiae}

The applicant submitted as follows:

1 Section 3 of the Act is unconstitutional as it prevents the attachment of state assets despite a court order;

2 the enforcement of a contempt order against a nominal defendant is neither appropriate or effective;

3 execution is the most effective and appropriate remedy;

4 the "red tape and bureaucracy" of the State makes it difficult to enforce contempt of court proceedings as it is not always possible to identify the relevant State official(s);

5 with regard to whether individuals can claim from the National Revenue Fund, "may" suggests this is discretionary. Even if it is not discretionary, an Act of Parliament is required to enable an individual to claim from such

$22 \mathrm{HC}$ case par 30.

23 The 2008 CC case par 4-6 and 25.

24 The 2008 CC case par 4-6. 
Fund (in this regard, the applicant referred to section 213 of the Constitution, and stated that execution would be more expeditious than claiming from the Funds) $;{ }^{25}$ and

6 the applicant's constitutional rights to equality, dignity and access to the courts were violated by the MEC. ${ }^{26}$

The respondents submitted as follows:

1 The section provides that the normal means of execution are not applicable to the State as judgment debtor, but does not violate the constitutional principle that court orders and decisions bind all persons (including organs of State);

2 it is not in the public interest if state assets are attached or sold in execution of a judgment debt;

3 the applicant was able to vindicate her rights by accessing the judicial system, and her right of access to courts was therefore not precluded by the section;

4 section 3 must be read together with the Public Finance Management Act 1 of 1999 (hereinafter the "PFMA") and the Treasury instructions;

5 section 3 authorizes the payment of a judgment debt sounding in money from the Funds; ${ }^{27}$

6 other remedies are available, for example, a mandatory order, committal for contempt of court, and a claim for damages; and

7 non-compliance with a court order by an organ of State can be reported to the Auditor-General or the Public Protector. ${ }^{28}$

The amicus curiae submitted as follows:

1 Section 3 is constitutionally compliant;

2 a finding of unconstitutionality will not be in the interest of the State;

3 judgment creditors can also look to the Funds to satisfy judgment debts;

4 an urgent mandamus is "quicker, cheaper, efficient and more backstraitening" method than the "slow, expensive, labouring steps" to levy execution; ${ }^{29}$ and

5 the reasoning in Magidimisl ${ }^{30}$ should be adopted. ${ }^{31}$

${ }^{25}$ S 2136 deals with the National Revenue Fund. S 213(2) states as follows:

"(2) Money may be withdrawn from the National Revenue Fund only -

(a) in terms of an appropriation by an Act of Parliament; or

(b) as a direct charge against the National Revenue Fund, when it is provided for in the Constitution or an Act of Parliament."

26 The 2008 CC case par 26-27.

27 The National Revenue Fund and the Provincial Revenue Fund.

28 The 2008 CC case par 29-30.

29 According to the CC, a mandamus "would essentially order the head of the State department to comply with court orders" (par 62).

30 Magidimisi NO $v$ The Premier of the Eastern Cape (ECD case No 2180/2004, 25 April 2006), unreported. In this case, Froneman $\mathrm{J}$ granted a mandamus with a structural interdict against provincial government. However, the CC approved of the applicant's opinion that this solution makes section 3 unconstitutional, "as an invitation to a judgment creditor to 


\section{Constitutional issue 1: Does section 3 of the Act limit any constitutional rights?}

Even though the applicant contended that section 3 violates sections $8,{ }^{32}$ $9(1),{ }^{33} 34,{ }^{34} 165,{ }^{35} 173^{36}$ and $195(1)(f)^{37}$ of the Constitution, the court only considered sections 9 and 10 . With regard to the equality clause (contained in section 9 of the Constitution), section 3 of the Act differentiates unjustifiably between the judgment creditors who obtain judgment against the State (these creditors are expressly prohibited from executing against State property) and those who obtain judgment against private litigants (these creditors are entitled to execute against a private litigant to obtain satisfaction of the debt). The court stated as follows: "[S]ection 3 disallows a judgment creditor who obtains judgment against the State the same protection and benefit that a judgment creditor who obtains judgment against a private litigant enjoys". ${ }^{38}$ In this regard, the following sections of the Constitution are relevant:

1 Section 8: The Bill of Rights applies to all law. It binds the Legislature, Executive and Judiciary, as well as all organs of State;

2 section 34: Everyone has the right to have a dispute that can be resolved by the application of law decided in a fair public hearing before a court;

3 section 164(4): "Organs of State, through legislative and other measures, must assist and protect the courts to ensure the independence, impartiality, dignity, accessibility and effectiveness of the courts"; and

seek a mandamus defies the harsh realities of litigation with its inherent concomitant risks and expenses".

31 The 2008 CC case par 31-33.

32 S 8(1) provides as follows: "The Bill of Rights applies to all law, and binds the legislature, the executive, the judiciary and all organs of state".

$33 \quad S$ 9(1) provides as follows: "Everyone is equal before the law and has the right to equal protection and benefit of the law".

34 S 34 deals with access to courts and provides as follows: "Everyone has the right to have any dispute that can be resolved by the application of law decided in a fair public hearing before a court or, where appropriate, another independent and impartial tribunal or forum".

35 S 165 deals with the judicial authority and provides as follows:

"(1) The judicial authority of the Republic is vested in the courts.

(2) The courts are independent and subject only to the Constitution and the law, which they must apply impartially and without fear, favour or prejudice.

(3) No person or organ of state may interfere with the functioning of the courts.

(4) Organs of state, through legislative and other measures, must assist and protect the courts to ensure the independence, impartiality, dignity, accessibility and effectiveness of the courts.

(5) An order or decision issued by a court binds all persons to whom and organs of state to which it applies."

${ }^{36}$ S 173 provides as follows: "The Constitutional Court, Supreme Court of Appeal and High Courts have the inherent power to protect and regulate their own process, and to develop the common law, taking into account the interests of justice."

37 S 195(1)(f) provides as follows:

"(1) Public administration must be governed by the democratic values and principles enshrined in the Constitution, including the following principles:

(f) Public administration must be accountable."

38 The 2008 CC case par 40. 
4 section 165(5): "An order or decision issued by a court binds all persons to whom and organs of State to which it applies".

These provisions clearly do not provide for differentiated treatment of State litigants (as opposed to private litigants); the court made it clear that "[d]eliberate non-compliance with or disobedience of a court order by the State detracts from the 'dignity, accessibility and effectiveness of the courts"' ${ }^{39}$ The CC concluded as follows: "Section 3 effectively places the State above the law. The section, as it stands, does not positively oblige the State to comply with court orders as it should. This is not compatible with the plain language of sections $8,34,165(4)$ and (5) of the Constitution". ${ }^{40}$

With regard to the right to dignity (contained in section 10 of the Constitution), the court stated as follows:

"It certainly cannot be said, in these circumstances, that the applicant was treated in a manner that showed recognition for his worth and importance as a human being. The State is under a duty to ensure that an individual's right to life is not infringed and is also under a duty to ensure that this right is protected."

As a result of the fact that the applicant only received payment of the interim amount just before he passed away, "[r]eliance on the State's goodwill and moral standards has in this case proved to be futile., ${ }^{42}$ It is clear that the constitutional provisions relating to dignity are also violated by section 3 of the Act. Section 3 therefore limits the rights contained in sections $9(1), 10$ and 34 of the Constitution. ${ }^{43}$

\section{Constitutional issue 2: Is the limitation reasonable in an open and democratic society based on human dignity, equality and freedom?}

The following aspects of the Constitution were relevant to the case at hand: ${ }^{44}$

1 The nature and purpose of the following rights:

a Access to courts;

b equality; and

c freedom;

2 the democratic principles of State accountability; and

3 the rule of law.

The CC found the limitations imposed by section 3 of the Act to be neither justifiable nor reasonable, and found the respondent's argument that the limitation serves to protect essential State assets from attachment and is

39 The 2008 CC case par 36-43. Quotation from par 43.

40 The 2008 CC case par 44.

41 The 2008 CC case par 45.

42 The 2008 CC case par 46.

43 The 2008 CC case par 46-47.

44 See also par 53 above. 
therefore justifiable and reasonable, unconvincing. ${ }^{45}$ The $\mathrm{CC}$ made it clear that the problem is located in the legislation and the State departments, and stated that even though State assets may not be attached, a State's ability to pay judgment debts is not inhibited. The court vowed to monitor the change required in government departments and the Office of the State Attorney.

\section{Constitutional issue 3: The proper interpretation of section 3 of the Act}

In order to ascertain whether the section is constitutionally compliant, the CC had to examine the effectiveness of the existing procedures relating to the satisfaction of judgment debts. With regard to claiming from the funds, both the PFMA and Treasury Regulations are relevant. Amongst others, prior written approval of the accounting officer is required before funds may be obligated from an institution. There are, however, no procedures (a) with regard to the settlement of court orders or (b) setting out how a litigant is to approach the Treasury or with whom to get in touch. The CC stated as follows:

"The procedures referred to are inaccessible to the majority of creditors and are far too complex to constitute a reasonable fulfilment of the State's obligations in terms of the Constitution. The section does not deal at all with how court orders are to be satisfied".

The CC considered a number of prior court cases that dealt with section 3 of the Act, and concluded that the courts have been facing immense challenges in this regard and have recognized that there is a serious problem caused by the fact the judgment creditors may find the orders sounding in money unenforceable against the State. The State has a duty to bring about the enforceability of court orders. ${ }^{48}$

With regard to the conduct of the State Attorney, the CC made its dissatisfaction very clear. The State Attorney never provided the applicant with reasons for non-payment or guidance with regard to when payment would be effected. The procedure of approaching the State Attorney is not effective - in this case payment was only made after the CC was approached by the applicant. The current procedure for approaching the State Attorney is "convoluted and difficult", largely unsuccessful, and involves a number of State institutions. In the present case there was a clear breakdown in communication between the MEC and the State Attorney. The CC stated that the State Attorney has in the past been made aware of the alarming state of affairs in its office, ${ }^{49}$ and that it (the CC) could not rely on the moral obligation on the State Attorney and the Department of Justice.

45 The court did, however, concede as follows: "I agree that the attachment of certain State assets, for example, ambulances and dialysis machines, would severely disrupt service delivery and would also unjustifiably limit the rights of many other individuals".

46 The 2008 CC case par 48-52.

47 The 2008 CC case par 53-58.

48 The 2008 CC case par 59-63.

49 South African Liquor Traders Association v Chairperson, Gauteng Liquor Board 20068 BCLR 901 (CC). 
The relevant State institutions were ordered to take steps to rectify the problems and report back to the CC. ${ }^{50}$

The PFMA (and its Regulations) contains provisions for internal disciplinary proceedings against accounting officers and officials, as well as for criminal offences in this regard. The CC found these procedures to be of no assistance in light of the "persistent inefficiency within State departments" ${ }^{51}$ The PFMA and its Regulations do not deal effectively with accounting authorities who disobey court orders, and it is not clear whether financial misconduct (as provided for in the PFMA and its Regulations) includes failure to pay judgment debts. The CC indicated that "[t]here is a desperate need for legislation to be enacted that will specifically target the areas of concern outlined in this judgment. The apathy of State officials in their failure to pay judgment debts cannot be addressed unless progressive, targeted steps are taken towards solving these problems. ${ }^{.52}$

According to the CC, contempt proceedings are not a viable option as a mandamus order first needs to be obtained. In addition, it does not "translate into money in the pocket for the judgment creditor" ${ }^{53}$ The CC added that "[o]nce a litigant is in possession of a judgment debt, he or she should not be expected to pursue the payment thereof ad infinitum" ${ }^{54}$ It is clear that procedures and mechanisms are lacking in order to enforce claims against the funds. State administration is inefficient and ineffective, and disciplinary action should be taken against defaulting State officials. In this regard, the CC stated as follows: "These State institutions need to look at these failings holistically and consider the best manner in which to deal with the problems at hand. This court is not in a position at this stage to assess the problems faced. ${ }^{.55}$

\section{Constitutional issue 4: An appropriate remedy}

As indicated above, it is clear that compliance with court orders cannot be enforced against the State. The CC indicated that "the failure of the State to edify its functionaries about the very legislation which governs their duties is unacceptable", and the fact that some officials do not know what their responsibilities are and legal representatives do not know who the responsible functionaries are, does not justify non-compliance. Contempt of court proceedings is not an effective process as it does not provide for money in the pocket of the creditor. ${ }^{56}$

With regard to the appropriate remedy, the court made its opinion very clear:

"This reliance on the moral obligation of the State to pay its debts is no longer acceptable, as it has proven to be unproductive and has revealed the State's

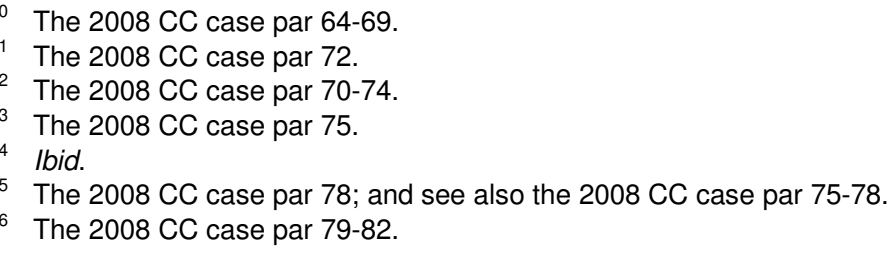


inability or refusal to abide by its own moral standards. Hence, we need legislative measures that will provide an effective way in which judgment orders may be satisfied, and mechanisms that will inform the litigants in detail on the procedures that they will need to follow regarding payment of court orders against the State. It has become necessary for this court to oversee the process of compliance with court orders and to ensure ultimately that compliance is both lasting and effective."

The Legislature must ensure the impartiality, efficiency and accessibility of the courts through the enactment of legislative measures. In this regard, the State must change the manner in which it deals with the satisfaction of debts. The CC suggested that attachment against the funds will have a minimal impact on the proper functioning of the State, but proper accounting procedures are necessary. The only effective way to ensure that all outstanding debts are satisfied is to make an appropriate order. In respecting the separation of powers doctrine, the Legislature had to be allowed to introduce mechanisms that would enable a judgment creditor to execute against the funds. ${ }^{58}$

\section{The issue as to costs and the court's order}

Costs were awarded against the respondents as they, as State organs, bear a special obligation to ensure that the work of the Judiciary is not impeded. The State's conduct was a "negligent disregard of an existing court order". ${ }^{59}$

The CC made the following order:

1 The order of constitutional invalidity made by the High Court was confirmed: "Section 3 of the State Liability Act is declared to be inconsistent with the Constitution to the extent that it does not allow for execution or attachment against the State and that it does not provide for an express procedure for the satisfaction of judgment debts";

2 the declaration of invalidity was suspended for a period of 12 months in order to allow Parliament to pass legislation that provides for the effective enforcement of court orders;

he Minister was ordered to provide the $\mathrm{CC}$ with a list of all unsatisfied court orders against all national and provincial State departments by no later than 31 July 2008. Further directions could be issued by the Chief Justice;

4 the Minister was required to provide the CC with a plan of the steps Government would take to ensure speedy settlement of unsatisfied court orders by no later than 31 July 2008; and

5 the respondents were ordered to pay the applicant's costs. ${ }^{60}$

Moseneke DCJ, Ngcobo J, Sachs J, Skweyiya J, Van der Westhuizen J and Yacoob $\mathrm{J}$ concurred in the judgment of Madala $\mathrm{J} .{ }^{61}$ Nkabinde $\mathrm{J}$ wrote a

57 The 2008 CC case par 83.

58 The 2008 CC case par 84-89.

59 The 2008 CC case par 91.

60 The 2008 CC case par 92.

61 The 2008 CC case par 91-92. 
minority judgment. Langa $\mathrm{CJ}$ and Mpati AJ concurred with the minority judgment.

\section{CONSTITUTION EIGHTEENTH AMENDMENT BILL, 2009}

On 1 June 2009 the Minister published ${ }^{63}$ the Constitution Eighteenth Amendment Bill of 2009 and the State Liability Bill, 2009 (hereinafter the "2009 Bill"), as Annexures A and B for public comment. The Constitution Eighteenth Amendment Bill contained only two clauses: clause 1 (containing the envisaged section 173A of the Constitution) (legal proceedings against State) and clause 2 (short title and commencement). The envisaged section 173A determined as follows:

“(1) Despite any other provision of the Constitution, an Act of Parliament must prescribe reasonable -

(a) procedural requirements for the institution of legal proceedings against the state;

(b) measures for enforcing the execution of final court orders against the state, including payments to be made by the state to comply with final court orders; and

(c) measures to enable the state to deal efficiently and effectively with all legal proceedings in which the state is involved.

(2) Section 226(2)(b) does not apply if the measures referred to in subsection (1)(b) authorise provincial governments to make payments as direct charges against the Provincial Revenue Funds when complying with final court orders.

(3) Different limitations, procedures and measures may be prescribed for different spheres of government or categories of the state or organs of state."

According to the Memorandum on the Objects of the Constitution Eighteenth Amendment Bill, the envisaged section 173A of the Constitution purported to give effect to the decision in the 2008 CC case ${ }^{65}$ and was "intended to lay the basis for the substitution of the State Liability Act,

62 The 2008 CC case par 93-153. According to the minority judgment, the non-compliance with the High Court order cannot be justified and authorized under $s 3$ of the Act, and, therefore, the section is not invalid. The minority judgment stated, amongst others, that the remedy of a mandamus is available in the case at hand. As a result, judgments can be enforced against the State. The prohibition contained in $s 3$ cannot be construed to mean that the State is above the law. In addition, s 3 does not limit the right to access to courts, as execution is a process which comes into play only after a court has reached its decision. According to the minority judgment, the prohibition serves a legitimate government purpose, and is "designed to prevent disruptions in the social fabric which may take place in the wake of attachments and executions against State assets" (the 2008 CC case par 142).

63 GN 689 in GG 32289 of 2009-06-01.

64 S 226 of the Constitution deals with the Provincial Revenue Funds. S 226(2)(b) states as follows:

"(2) Money may be withdrawn from a Provincial Revenue Fund only -

(a) in terms of an appropriation by a provincial Act; or

(b) as a direct charge against the Provincial Revenue Fund, when it is provided for in the Constitution or a provincial Act."

65 Par 1.5 of the Memorandum on the Objects of the Bill. 
1957 ". ${ }^{66}$ The current section 173 of the Constitution vests, amongst others, the (exclusive) inherent power to determine appropriate procedures to give effect to judgments in the courts:

"The Constitutional Court, Supreme Court of Appeal and High Courts have the inherent power to protect and regulate their own process, and to develop the common law, taking into account the interests of justice."

Notwithstanding this explicit constitutional provision, the envisaged section 173A of the Constitution made it clear, "despite any other provision of the Constitution" ${ }^{67}$ that the proposed State Liability Bill, 2009, should prescribe reasonable procedural requirements for the institution of legal proceedings against the State and measures for (a) enforcing the execution of final court orders, and (b) the empowerment of the State to deal appropriately with legal proceedings instituted against it. In addition, the envisaged section $173 \mathrm{~A}(2)$ of the Constitution provided for the exclusion of the current section 226(2)(b) of the Constitution (which sets out a framework for the withdrawal of money from a Provincial Revenue Fund). ${ }^{68}$ Finally, the proposed section $173 \mathrm{~A}(3)$ of the Constitution authorized the enactment (by means of the proposed national legislation) of different sets of limitations, procedures and measures for the various spheres of government and organs of state (as well as for "different ... categories of the state" 69 - a term which was not defined or explained in the Constitution Eighteenth Amendment Bill, 2009, the State Liability Bill, 2009, or the Memoranda on the Objects of these two 2009 Bills, and which is, moreover, not used in the Constitution at all).

It is clear that the attempt to circumvent the Constitution by introducing the envisaged section 173A of the Constitution that would, if enacted, allow national legislation to trump the Constitution, was undoubtedly unconstitutional taking into account, amongst others, section 2 of the Constitution which states as follows:

"This Constitution is the supreme law of the Republic; law or conduct inconsistent with it is invalid, and the obligations imposed by it must be fulfilled."

\section{STATE LIABILITY BILL, 2009}

Although the 2009 Bill, purported "to rectify the unconstitutionality of the State Liability Act, 1957 (Act No. 20 of 1957), ${ }^{70}$ the responses of various academics and NGOs in respect of the Constitution Eighteenth Amendment Bill, 2009, and/or the 2009 Bill $^{71}$ clearly indicated that the Bill did not give

\footnotetext{
Par 2.3 of the Memorandum on the Objects of the Bill.

Authors' own emphasis.

8 See fn 63 above.

Authors' own emphasis.

70 Memorandum on the Objects of the State Liability Bill, 2009, par 1.1.

71 De Vos "Constitutional Eighteenth Amendment Bill: Parliamentary Submission" http://www.constitutionallyspeaking.co.za/coming-soon-2/, IDASA "Submission on the Draft Constitution $18^{\text {th }}$ Amendment Bill, 2009, and the Draft State Liability Bill, 2009" 8 July 2009 http://www.idasa.org/media/uploads/outputs/files/Con\%2018th\%20-\%20website.pdf; De Vos "Between Moral Authority and Formalism: Nyathi v Member of Executive Council for Dept of
} 
effect to the unambiguous decision in the 2008 CC case. According to the Memorandum on the Objects of the 2009 Bill, the objects of the 2009 Bill were as follows:

"2.1 The Bill seeks to replace the State Liability Act, 1957, in order to make provision for-

(a) procedural requirements for the institution of legal proceedings against the state;

(b) measures for enforcing the execution of final court orders against the state, including payments to be made by the state to comply with final court orders; and

(c) measures to enable the state to deal efficiently and effectively with all legal proceedings in which the state is involved."

The 2009 Bill was composed of the following six parts and three schedules: Part 1: Notice (including notice of intended legal proceedings and the service thereof); Part 2: Process (including service, cognizable claims and arrangements relating to the executing authority concerned); Part 3 : Enforcement of final court orders sounding in money (including the satisfaction of final court orders); Part 4: Responsibility for litigation and settlement of debt, and reporting (including authorization by both the executing authority and the accounting officer for litigation or settlement of debt and the keeping of statistics of litigation); Part 5: Accountability (including civil claims against the State or its employees and arrangements relating to criminal matters); and Part 6: Miscellaneous (including regulations, savings, amendment and the repeal of laws, transitional arrangements, short title and commencement). Schedule 1 dealt with amended or repealed laws, Schedule 2 dealt with the pro forma application and undertaking with regard to civil matters (in accordance with clause 11 of the 2009 Bill) to be signed by the official concerned and his/her accounting officer, and Schedule 3 dealt with a similar pro forma in the case of criminal matters (in accordance with clause 12 of the 2009 Bill).

Notwithstanding the decision in the 2008 CC case, the 2009 Bill in fact envisaged the continuation of the pre-2008 approach:

"It (the 2009 Bill) starts from the same premise that there should be no execution, attachment or like process against the State or the property of the State, but provides that the final court order sounding in money must be satisfied within 30 days of the order being given."

The core content of the 2009 Bill was to prohibit any final court order that would allow execution, attachment or like process, and only to allow final court orders sounding in money. In this regard, clause 7(1) stated as follows:

"No execution, attachment or like process may be issued against the defendant or respondent in any action or legal proceedings against the state or against any property of the state, but the amount, if any, which may be required to satisfy any final court order against the nominal defendant or respondent in any such action or proceedings must be paid as contemplated in this section."

Health, Gauteng" 20092 Constitutional Court Review 409-427; Muthwa "Address on the Occasion on the Launch of the Book "Government Liability" 26 May 2010 East London http://www.ufh.ac.za/files/speech.pdf.

72 The Memorandum on the Objects of the State Liability Bill, 2009, par 2.3(g). 
In addition, clause 7(2) determined that no pre-final (interim) orders for payment (with the exception of relief for "urgent or necessary medical treatment") may be given by any court:

"Despite the common law or any other law to the contrary, except for interim relief for urgent or necessary medical treatment, a court may not order any payment contemplated in subsection (1) at any stage of the proceedings except when giving a final court order."

The procedure proposed by the 2009 Bill entailed the following: In the first instance, the accounting officer concerned must effect payment within 30 days of the order having become final. ${ }^{73}$ However, if the organ of state does not have sufficient funding, other avenues are to be followed (for example, the provision of intervention support by the national or provincial treasury concerned). ${ }^{74}$ If that does not result in payment, the judgment creditor may give a ten-days' notice to the accounting officer, the head of the department concerned and the head of Treasury to explain to the court why payment has not been effected. ${ }^{75}$ As part of the approach that "the court then has a wide discretion to act as it deems fit", "an accounting officer who fails to comply with the provisions regarding payment is liable to contempt of court or to a charge of financial misconduct".

The above brief overview of the 2009 Bill clearly indicates that the object, scheme and key provisions of the 2009 Bill offended the Constitution (and specifically section 173 - see discussion above), notwithstanding the declared explicit aim "to rectify the unconstitutionality of the State Liability Act, 1957 (20 of 1957)",78 and "to address the CC's judgment in the Nyathi case".

The Department of Justice and Constitutional Development subsequently decided not to proceed with the Constitution Eighteenth Amendment Bill of 2009 and the 2009 Bill, and to start de novo with the drafting of legislation that would give effect to the judgment in the 2008 CC case.

\section{POST-2008 CC: BRIEF OVERVIEW OF CASES AND COURTS' INTERPRETATION OF 2008 CC CASE}

In Van Straaten $v$ President of the Republic of South Africa ${ }^{80}$ the CC commented, amongst others, on the State's failure to respond to a matter that was before the court. The court referred, amongst others, to the 2008 CC case and stated that State had in a number of other cases also failed to

73 Clause 7(3)(a)-(b).

74 Clauses 7(3)(c)-(d) and 7(4)-(6).

75 Clause $7(8)$.

76 Clause 7(9)-(11). See also the Memorandum on the Objects of the State Liability Bill, 2009, par 2.3(g).

77 Clause 7(12) and the Memorandum on the Objects of the State Liability Bill, 2009, par 2.3(g).

78 The Memorandum on the Objects of the State Liability Bill, 2009 par 1.1.

79 The Memorandum on the Objects of the Constitution Eighteenth Amendment Bill, 2009 par 1.5. The so-called Nyathi case refers to the 2008 CC case.

8020093 SA 457 (CC). 
respond, and that steps need to be taken in order to prevent the same from happening again in the future. ${ }^{81}$

In Golden Arrow Bus Services (Pty) Ltd v Minister of Transport ${ }^{82}$ the court also referred to the $2008 \mathrm{CC}$ case. However, the case at hand did not deal with the unwillingness of the State to pay a debt, but rather with the State's legal ability to effect payment. The Treasury only allowed the withdrawal of money from the National Revenue Fund if it was (a) authorized in terms of an appropriation by an Act of Parliament or (b) authorized as a so-called "direct charge" in terms of section 15 of the PFMA. ${ }^{83}$ The court examined section 165(5) of the Constitution, ${ }^{84}$ and made it clear that judgments against the State sounding in money constituted debts which were direct charges against the National (or Provincial) Revenue Fund. As a result, the court found no statutory bar to the immediate settlement of the claim from the National Revenue Fund. ${ }^{85}$

In two other cases, the courts very briefly referred to the 2008 CC case, namely in Head of Department, Mpumalanga Department of Education $v$ Hoërskool Ermelo, ${ }^{86}$ and in Quinella Trading (Pty) Ltd v Minister of Rural Development. ${ }^{87}$

\section{NYATHI 2010 CONSTITUTIONAL COURT CASE}

In the second CC case ${ }^{88}$ (hereinafter the "2010 CC case") the Minister applied to the CC for an extension of the period of suspension of the CC order of constitutional invalidity. ${ }^{89}$ The Chief Justice issued directions inviting parties who wished to oppose the application to file submissions. The following parties were admitted as amicus curiae: the AIDS Law Project (hereinafter the "ALP"), the Legal Resources Centre (hereinafter the "LRC"), and Freedom under Law (hereinafter "FUL"). In addition, the Law Society of South Africa (hereinafter the "Law Society") was admitted as an intervening party. ${ }^{90}$

The reports the Minister was ordered to provide to the CC were filed on 31 July 2008, 12 December 2008 and 5 August 2009, and, amongst others, reported on progress made regarding the preparation of the 2009 Bill and the Constitution Eighteenth Amendment Bill. Even though the 2009 Bill had

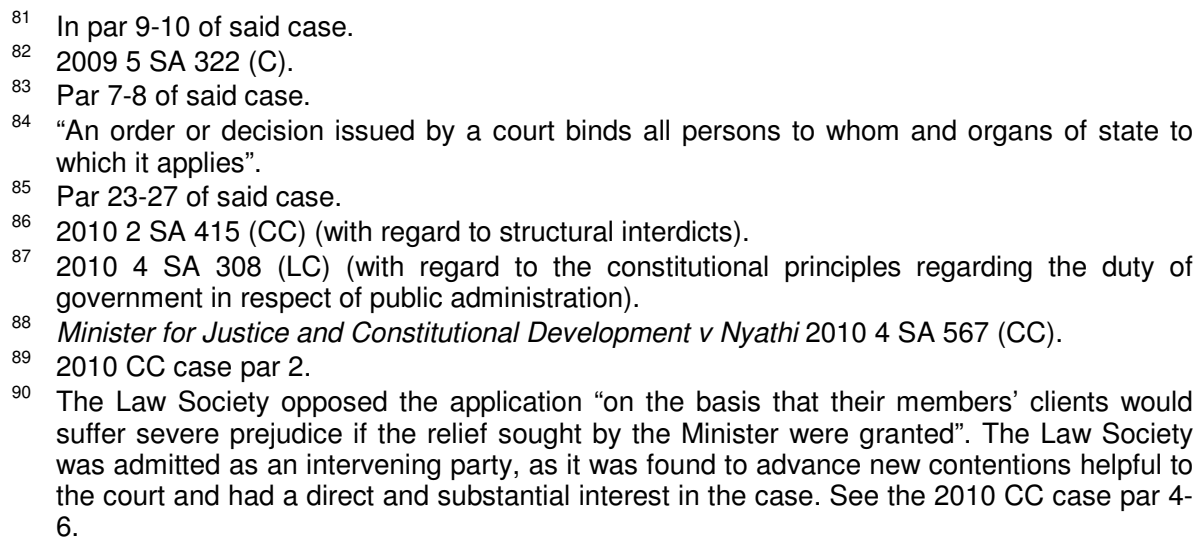

90 The Law Society opposed the application "on the basis that their members' clients would suffer severe prejudice if the relief sought by the Minister were granted". The Law Society was admitted as an intervening party, as it was found to advance new contentions helpful to the court and had a direct and substantial interest in the case. See the 2010 CC case par 46 . 
been in preparation since 2003, it was only tabled before the Cabinet Committee on Governance and Administration on 3 December 2008, where it was approved for public comment (subject to consultation with the Minister of Finance prior to its publication, which only commenced four months later). The 2009 Bill and the Constitution Eighteenth Amendment Bill were published in an Extraordinary Government Gazette on 1 June 2009 for public comment (one day before the expiry of the suspension period). On the same day, the Minister filed an urgent application for an order to extend the period of suspension of the 2008 CC order (enactment of new legislation) for a further 12 months. Pursuant to the application, the CC made an order on 1 June 2009 that the period of suspension be extended until 31 August 2009 (for the "full airing of the issues and for consideration of the interests of the public"). The remainder of the urgent application for the variation of the order of 2 June 2008 (the 2008 CC case) was postponed to 12 August 2009 for hearing. ${ }^{91}$

\section{Application for extension: The Minister's submissions}

According to the Minister, the Bill could not be passed in the specified time period as a result of the following reasons: (a) the national elections in 2009; (b) the shorter parliamentary session; (c) the need to engage other government departments; (d) the difficult consultation process and research necessary; as well as (e) the fact that the team was tasked with a range of other legislative responsibilities. The Minister submitted that administrative chaos would ensue if the order was not granted, which would result in wideranging prejudice if essential assets were attached. However, it was submitted, there would be little prejudice to the public if the order was granted as the Department had satisfied the majority of cases which were outstanding on 31 July 2008. If the application were to be refused, there would be greater prejudice to the Government than to those who still had outstanding judgment debts. The Minister submitted that the time period granted was irrational, idealistic and neither realistic nor achievable, and that an extension should be granted to 31 May 2010. However, the Minister could not with certainty say when the Bills would be passed. ${ }^{92}$

\section{Submissions by the amici curiae and the intervening party}

The ALP submitted as follows:

1 There was no risk of widespread attachment of State assets as it was submitted by the Minister that only R3,5 million in debt remained outstanding;

2 prejudice to the public outweighed any prejudice the State might suffer;

\footnotetext{
2010 CC case par 7-11.

922010 CC case par 12-16.
} 
3 with reference to the factors in Ex Parte Minister of Social Development, ${ }^{93}$ an extension was not warranted;

4 there was non-compliance with the suspension order, inadequate explanation for the delay and an indefinite plan proposed by Minister;

5 the urgency pleaded was mostly occasioned by the Minster's own making;

6 the Minister had been ambivalent as to when Bills were expected to be passed into law; and

7 interim relief should be granted to protect constitutional rights.

The ALP proposed an order that the Minister designate a fund against which execution of judgment orders can be levied. ${ }^{94}$

The LRC made similar submissions than those of the ALP, but added as follows:

1 Prejudice would be suffered by indigent clients and their own inability to recover costs; and

2 insufficient evidence was provided regarding the anticipated public prejudice. $^{95}$

FUL submitted as follows:

1 The conduct of the Minister infringed the rule of law as the Minister failed to enact relevant legislation timeously; and

2 an extension would "imply a sanctioning of the continued violation of the Constitution, which is at odds with the imperatives of a constitutional democracy and the rule of law". ${ }^{9}$

However, the FUL added that if the CC made an interim order that allows for the effective enforcement of judgment debts against the State, it would be irrelevant if an extension was to be granted or not. The FUL submitted that the State should be directed (in an interim order) to designate a fund to which application may be made for the satisfaction of judgment debts against the State. ${ }^{97}$

The Law Society also made submissions similar to those of the amici curiae, and also added suggestions regarding a possible interim order. ${ }^{98}$

\section{Factors to be taken into account}

The CC considered whether it had the power to vary and extend the period of suspension of a declaration of invalidity, quoted Zondi $I I,{ }^{99}$ and concluded that it has a discretion in this regard. The CC stated that a decision must not

93 Ex Parte Minister of Social Development 20064 SA 309 (CC).

942010 CC case par 17-19.

2010 CC case par 20.

962010 CC case par 21-22.

97 Ibid.

2010 CC case par 23

99 Zondi v MEC, Traditional and Local Government Affairs 20063 SA 1 (CC). 
only be informed by the following principles (as set out in Ex Parte Minister of Social Development), ${ }^{100}$ but must also be rooted in them:

1 Whether a sufficient explanation for the failure to comply with the original period of suspension was provided;

2 what the potentiality of prejudice being sustained is if an extension is granted or not granted;

3 what the prospects of compliance with the deadline is;

4 "[t]he need to bring litigation to finality"; and

5 "[t]he need to promote the constitutional project and prevent chaos". ${ }^{101}$

\section{The interim court order of 31 August 2009}

The court made the following order on 31 August 2009:

"1 The period of suspension of invalidity in para 2 of the order granted in Nyathi v MEC for Department of Health, Gauteng and Another 2008 (5) SA 94 (CC), as extended by an order of this court granted on 1 June 2009, is further extended until 31 August 2011.

2 The parties to this case, as well as the Minister for Finance, are requested to lodge written argument on or before 15 September 2009 on the question of whether an order in the following terms should be made an order of court to be operative during the period of suspension made in para 1 of this order:

'During the extended period of suspension granted by this court on 31 August 2009, or until legislation regulating the matter is brought into effect, the following process for the enforcement of court orders against the State sounding in money shall apply:

(a) If a final court order against the State for the payment of money is not satisfied within 30 days of the date of judgment, the judgment creditor may serve notice on the State Attorney and the relevant Accounting Officer in the National or Provincial Department or the local government of the intention to attach movable property owned by the State and used by the department which is, in effect, the judgment debtor for the purposes of a sale in execution to satisfy the judgment debt.

(b) If, within 14 days after the notice in para (a) of this order has been served, the judgment debt remains unpaid, the judgment creditor may apply for a writ of execution against movable property in terms of rule 45 of the Uniform Rules of Court or in terms of rule 36 of the Magistrates' Courts Rules of Court, whichever is applicable.

(c) The sheriff of the relevant court shall, pursuant to the writ of execution, attach movable property owned by the State and used by the relevant department.

(d) 30 days after the date of the attachment, and in the absence of any application as contemplated in para (e) of this order, the sheriff of the relevant court may sell the attached movable property in execution of the judgment debt.

(e) Any affected party may, during the periods referred to in paras (b) and (d) of this order, apply to the court which granted the judgment in question for an order staying the execution contemplated in para (d) on the ground that it is not in the interests of justice and good governance

100 Ex Parte Minister of Social Development supra.

1012010 CC case par 24-30. See also Ex Parte Minister of Social Development supra. 
to attach and sell in execution the movable property of the State which has been attached.

(f) The duty to establish that it would not be in the interests of justice and good governance for the property of the State which has been attached to be sold in execution rests upon the party seeking the relief sought in paragraph (e) of this order.'

3 The parties to this case, as well as the Minister for Finance, may also submit written argument on or before 15 September 2009 proposing an alternative order for the timeous and effective enforcement of judgment debts.

4 The registrar of this court is instructed to arrange for service of a copy of this order, as well as a copy of this court's judgment in Nyathi v MEC for Department of Health, Gauteng and Another 2008 (5) SA 94 (CC) on the Minister for Finance.

5 Costs are reserved." 102

\section{The reasons for the granting of the order of 31 August 2009}

The reasons provided for the granting of an extension order were as follows:

1 Given the number of government departments and spheres of government, as well as the complexity of the issues, the CC found it reasonable to anticipate an extended timespan before the Bills would be passed; and

2 a longer period of extension than usual was warranted, just and equitable. The period of extension was for another two years, subject to an interim order regulating the enforcement of judgment debts against the State (a rule nisi was granted in this regard).

The reasons provided for the granting of an interim order were as follows:

1 It was necessary to protect judgment creditors against the continued infringement of their rights resulting from the failure to pass legislation timeously; and

2 in the absence of an interim order, the rules of statutory and common law may apply. As a result, there will be no guarantee that the attachment and execution of vital State property will not take place (which will affect essential public-service delivery). ${ }^{104}$

The CC stated as follows: "[W]ithout a further suspension, coupled with an interim order to protect judgment creditors' interests in the meanwhile, the broader public prejudice may in some instances be grave". ${ }^{105}$

\footnotetext{
2010 CC case par 31

1032010 CC case par 32.

1042010 CC case par 33.

${ }^{105} 2010$ CC case par 34.
} 


\section{Written submissions regarding the proposed interim order of 31 August 2009}

The Minister for Finance presented a procedure to the CC in terms whereof a judgment creditor can serve the relevant treasury with a final judgment order for payment. Payment will be effected by the Treasury and set off against the budget allocation of the relevant department. If payment is not made within 30 days of the judgment, the judgment creditor can serve the judgment order (in terms of Rule 4 of the Uniform Rules of Court) on the relevant treasury, the State Attorney, the accounting officer of the national or provincial department, and the executive authority of the department. The judgment order has to be accompanied by a certification of its validity and finality by the Registrar or Clerk of the Court. If the judgment debt remains unpaid 14 days after service, the relevant treasury will then: (a) cause the debt to be settled; (b) settle the debt itself; or (c) make acceptable arrangements with the judgment creditor for settlement. ${ }^{106}$

It was submitted by the ALP and FUL that the inclusion of an attachment and execution procedure against assets of local government is unnecessary as section 3 of the Act does not regulate debts against local government. ${ }^{107}$ With regard to who may apply for the stay of an execution order, FUL submitted that the term "a party having a direct and material interest" be used instead of "any affected party" as the first-mentioned term limits the class of affected parties. It was added that "[t]his, of course, does not affect any party other than the State who has a basis in law to prevent the execution". ${ }^{108}$

With regard to when a stay of execution order should be granted, FUL submitted that the standard should be whether it would be in the interests of justice and necessary to prevent disruption to the performance of essential public service. The CC concurred that the test for good governance may be elusive. After considering the provisions of the Local Government: Municipal Finance Management Act 56 of 2003 (hereinafter the "MFMA"), the court found that it would be better to use the test relating to the "interests of justice". However, last-mentioned test's "relative and broad basis may unduly immunise State assets from attachment and execution". Considerations similar to those set out in the MFMA are taken into account when applying the test. The CC stated that "[o]rdinarily it will be in the interests of justice to grant a stay where the assets to be attached are reasonably necessary to sustain effective administration or to provide a minimum level of basic services. That will be for a court to decide". The ALP further submitted that a court must consider whether suitable alternative property has been identified by the party seeking the stay. This will avoid undue delays and litigation, as well as further prejudice. ${ }^{109}$

\footnotetext{
2010 CC case par 35-38.

2010 CC case par 39

1082010 CC case par 40.

1092010 CC case par 41-44. The ALP submitted that par 2(e) of the proposed interim order may result in a successful application for an order staying the execution being followed by
} 
Relating to costs orders in stay applications, the LRC submitted that the proposed interim order must provide for a costs order against the unsuccessful applicant on an attorney-and-client scale (save for exceptional circumstances). The CC, however, stated that a court must have an unfettered discretion in this regard - based on the facts, circumstances and applicable legal principles. ${ }^{11}$

\section{The court order}

The CC considered the submissions by the Minister of Finance, and found that the proposed procedure, even though quick, more accessible and ensuring accountability of State functionaries, does not provide for a remedy if the treasury functionaries fail to effect payment within a reasonable time or at all. It does not make "room for likely systemic difficulties which might affect administrative efficiency". The proposed procedure should therefore be combined with the order of 31 August 2009. With regard to the time frames, the CC stated that since the judgment creditor will have waited 44 days from the judgment date under the Treasury payout procedures, it would not be necessary for an extensive period under the attachment and execution procedures (the timelines in the 31 August 2009 order had to be tightened). The proposed waiting periods have also been curtailed. ${ }^{111}$

The CC set out the integrated payout plan and stated that the aggregate time period from final judgment to the date of execution would be approximately 75 days. The procedures and time periods will operate within the applicable statutory frameworks (for example, the Magistrates' Courts Act 32 of 1944 and the Supreme Court Act 59 of 1959). The CC declined to adopt the Minister's suggestion that a Treasury payout procedure should not apply to default judgments against the State by the Registrar or Clerk of the court, ${ }^{112}$ and added that the State will always have the option to apply for the rescission of a default judgment if it has been granted erroneously or fraudulently. The CC reiterated the importance of the ability of judgment creditors to obtain effective relief. ${ }^{113}$

The Minister also proposed that the provincial treasuries be invited to comment on his submissions, but the CC stated that the provinces' views should have been included in the Minister's submissions. ${ }^{114}$

The following order was made by the CC on 9 October 2009:

"1 The application of the Law Society of South Africa to be admitted as an intervening party is granted.

2 The applicant's application for condonation for late filing is granted.

another application for a stay if the judgment creditor obtains a second writ of execution in respect of other property.

1102010 CC case par 45-46.

1112010 CC case par 47-50.

112 The Minister submitted that judgments against the State warrant the attention of a judge or magistrate (instead of the Registrar or Clerk of a court).

1132010 CC case par 51-52.

1142010 CC case par 53. 
3 The following interim order shall apply during the period of extension in para 1(1) of this court's order of 31 August 2009:

(a) If a final order against a national or provincial department for the payment of money is not satisfied within thirty (30) days of the date of judgment, the judgment creditor may serve the court order in terms of rule 4 of the Uniform Rules of Court, or rule 9 of the Magistrates' Courts Rules, on the relevant national or provincial treasury, the State Attorney, the accounting officer of the relevant national or provincial department, as well as the Executive Authority of the Department concerned.

(b) The court order served on the officials referred to in para (a) of this order must be accompanied by a certificate by the registrar or clerk of the relevant court, certifying that no appeal, review or rescission proceedings are pending in respect thereof.

(c) The relevant treasury shall within fourteen (14) days of service of the order, cause the judgment debt to be settled, or itself settle the judgment debt, or make acceptable arrangements with the judgment creditor for the settlement of the judgment debt.

(d) Should the relevant treasury fail to cause the judgment debt to be satisfied, itself settle the debt or make acceptable arrangements with the judgment creditor for the settlement of the judgment debt within the time period specified in para (c) of this order, the judgment creditor may apply for a writ of execution in terms of rule 45 of the Uniform Rules of Court, or a warrant of execution in terms of rule 36 of the Magistrates' Courts Rules, against movable property owned by the State and used by the relevant department, whichever is applicable.

(e) The sheriff of the relevant court shall, pursuant to the writ of execution or warrant of execution, attach, but not remove, the identified movable property.

(f) In the absence of any application contemplated in para (g) of this order, the sheriff of the relevant court may, after the expiration of thirty (30) days from the date of attachment, remove and sell the attached movable property in execution of the judgment debt.

(g) A party having a direct and material interest may, during the periods referred to in para (f) of this order, apply to the court which granted the order, for a stay on grounds that the execution of the attached assets is not in the interests of justice.

4 There is no order as to costs." 115

Langa CJ, Moseneke DCJ, Cameron J, Ngcobo J, Nkabinde J, O’Regan $\mathrm{J}$, Sachs $\mathrm{J}$, Skweyiya $\mathrm{J}$ and Van der Westhuizen $\mathrm{J}$ concurred with the judgment of Mokgoro J.

1152010 CC case par 57 . The ALP and the Law Society asked that costs in their applications be costs in the cause. In par 54-56, the court set out the reasons why no costs order was made. As a result of the fact the Law Society has raised important constitutional issues, and that it is a general rule that no costs order is made against private litigants who raised such issues, the court found that even though an extension was granted, it would not be appropriate to make a costs order against the Law Society as the intervening party (who, in effect, played the part of an amicus.) With regard to the ALP, the rule is that amici curiae are generally not entitled to costs, except where exceptional circumstances warrant same. The court could not find such exceptional circumstances. 


\section{Comparison between the 31 August 2009 and 9 October 2009 orders}

The following table provides a comparison between the 31 August 2009 summary order and the 9 October 2009 order: ${ }^{116}$

\begin{tabular}{|c|c|}
\hline $\begin{array}{l}\text { The summary order of } 31 \text { August } \\
2009 \text { regarding the process to be } \\
\text { followed }\end{array}$ & $\begin{array}{l}\text { The } 9 \text { October } 2009 \text { order regarding } \\
\text { the process to be followed }{ }^{118}\end{array}$ \\
\hline $\begin{array}{l}\text { The parties to this case, as well as } \\
\text { the Minister for Finance, are } \\
\text { requested to lodge written argument } \\
\text { on or before } 15 \text { September } 2009 \text { on } \\
\text { the question of whether an order in } \\
\text { the following terms should be made } \\
\text { an order of court to be operative } \\
\text { during the period of suspension } \\
\text { made in para } 1 \text { of this order: } \\
\text { "During the extended period of } \\
\text { suspension granted by this court } \\
\text { on } 31 \text { August } 2009 \text {, or until } \\
\text { legislation regulating the matter is } \\
\text { brought into effect, the following } \\
\text { process for the enforcement of } \\
\text { court orders against the State } \\
\text { sounding in money shall apply: }\end{array}$ & $\begin{array}{l}\text { The following interim order shall apply } \\
\text { during the period of extension in para 1(1) } \\
\text { of this court's order of } 31 \text { August 2009: }\end{array}$ \\
\hline $\begin{array}{l}\text { (a) If a final court order against the } \\
\text { State for the payment of money is } \\
\text { not satisfied within } 30 \text { days of the } \\
\text { date of judgment, the judgment } \\
\text { creditor may serve notice on the } \\
\text { State Attorney and the relevant } \\
\text { Accounting Officer in the National } \\
\text { or Provincial Department or the } \\
\text { local government of the intention } \\
\text { to attach movable property } \\
\text { owned by the State and used by } \\
\text { the department which is, in effect, } \\
\text { the judgment debtor for the } \\
\text { purposes of a sale in execution to }\end{array}$ & $\begin{array}{l}\text { (a) If a final order against a national or } \\
\text { provincial department for the payment } \\
\text { of money is not satisfied within thirty } \\
\text { (30) days of the date of judgment, the } \\
\text { judgment creditor may serve the court } \\
\text { order in terms of rule } 4 \text { of the Uniform } \\
\text { Rules of Court, or rule } 9 \text { of the } \\
\text { Magistrates' Courts Rules, on the } \\
\text { relevant national or provincial } \\
\text { treasury, the State Attorney, the } \\
\text { accounting officer of the relevant } \\
\text { national or provincial department, as } \\
\text { well as the Executive Authority of the } \\
\text { Department concerned. }\end{array}$ \\
\hline & $\begin{array}{l}\text { (b) The court order served on the officials } \\
\text { referred to in para (a) of this order } \\
\text { must be accompanied by a certificate } \\
\text { by the registrar or clerk of the relevant } \\
\text { court, certifying that no appeal, review } \\
\text { or rescission proceedings are } \\
\text { pending in respect thereof. }\end{array}$ \\
\hline & $\begin{array}{l}\text { (c) The relevant treasury shall within } \\
\text { fourteen (14) days of service of the } \\
\text { order, cause the judgment debt to be } \\
\text { settled, or itself settle the judgment } \\
\text { debt, or make acceptable } \\
\text { arrangements with the judgment } \\
\text { creditor for the settlement of the }\end{array}$ \\
\hline
\end{tabular}




\begin{tabular}{|c|c|}
\hline $\begin{array}{l}\text { The summary order of } 31 \text { August } \\
2009 \text { regarding the process to be } \\
\text { followed }\end{array}$ & $\begin{array}{l}\text { The } 9 \text { October } 2009 \text { order regarding } \\
\text { the process to be followed }{ }^{118}\end{array}$ \\
\hline $\begin{array}{l}\text { (b) If, within } 14 \text { days after the notice } \\
\text { in para (a) of this order has been } \\
\text { served, the judgment debt } \\
\text { remains unpaid, the judgment } \\
\text { creditor may apply for a writ of } \\
\text { execution against movable } \\
\text { property in terms of rule } 45 \text { of the } \\
\text { Uniform Rules of Court or in } \\
\text { terms of rule } 36 \text { of the } \\
\text { Magistrates Courts Rules of } \\
\text { Court, whichever is applicable. }\end{array}$ & $\begin{array}{l}\text { (d) Should the relevant treasury fail to } \\
\text { cause the judgment debt to be } \\
\text { satisfied, itself settle the debt or make } \\
\text { acceptable arrangements with the } \\
\text { judgment creditor for the settlement of } \\
\text { the judgment debt within the time } \\
\text { period specified in para (c) of this } \\
\text { order, the judgment creditor may } \\
\text { apply for a writ of execution in terms } \\
\text { of rule } 45 \text { of the Uniform Rules of } \\
\text { Court, or a warrant of execution in } \\
\text { terms of rule } 36 \text { of the Magistrates' } \\
\text { Courts Rules, against movable } \\
\text { property owned by the State and } \\
\text { used by the relevant department, } \\
\text { whichever is applicable. }\end{array}$ \\
\hline $\begin{array}{l}\text { (c) The sheriff of the relevant court } \\
\text { shall, pursuant to the writ of } \\
\text { execution, attach movable } \\
\text { property owned by the State and } \\
\text { used by the relevant department. }\end{array}$ & $\begin{array}{l}\text { (e) The sheriff of the relevant court shall, } \\
\text { pursuant to the writ of execution or } \\
\text { warrant of execution, attach, but not } \\
\text { remove, the identified movable } \\
\text { property. }\end{array}$ \\
\hline $\begin{array}{l}\text { (d) } 30 \text { days after the date of the } \\
\text { attachment, and in the absence } \\
\text { of any application as } \\
\text { contemplated in para (e) of this } \\
\text { order, the sheriff of the relevant } \\
\text { court may sell the attached } \\
\text { movable property in execution of } \\
\text { the judgment debt. }\end{array}$ & $\begin{array}{l}\text { (f) In the absence of any application } \\
\text { contemplated in para }(g) \text { of this order, } \\
\text { the sheriff of the relevant court may, } \\
\text { after the expiration of thirty (30) days } \\
\text { from the date of attachment, remove } \\
\text { and sell the attached movable } \\
\text { property in execution of the judgment } \\
\text { debt. }\end{array}$ \\
\hline $\begin{array}{l}\text { (e) Any affected party may, during } \\
\text { the periods referred to in paras } \\
\text { (b) and }(d) \text { of this order, apply to } \\
\text { the court which granted the } \\
\text { judgment in question for an order } \\
\text { staying execution } \\
\text { contemplated in para }(d) \text { on the } \\
\text { ground that it is not in the } \\
\text { interests of justice and good } \\
\text { governance to attach and sell in } \\
\text { execution the movable property } \\
\text { of the State which has been } \\
\text { attached. }\end{array}$ & $\begin{array}{l}\text { (g) A party having a direct and material } \\
\text { interest may, during the periods } \\
\text { referred to in para ( } f \text { ) of this order, } \\
\text { apply to the court which granted the } \\
\text { order, for a stay on grounds that the } \\
\text { execution of the attached assets is } \\
\text { not in the interests of justice. }\end{array}$ \\
\hline $\begin{array}{l}\text { (f) The duty to establish that it would } \\
\text { not be in the interests of justice } \\
\text { and good governance for the } \\
\text { property of the State which has } \\
\text { been attached to be sold in } \\
\text { execution rests upon the party } \\
\text { seeking the relief sought in } \\
\text { paragraph }(e) \text { of this order. }\end{array}$ & \\
\hline
\end{tabular}

The main differences between the 31 August 2009 and the 9 October 2009 orders can be summarized as follows:

1 In terms of the 9 October 2009 order, the court order (accompanied by a certificate certifying no appeal review or rescission proceedings are 
pending) must be served on the relevant national or provincial treasury, the State Attorney, the accounting officer of the relevant national or provincial treasury and the Executive Authority of the department concerned. In terms of the 31 August 2009 order, a notice setting out the intention to attach movable property owned by the State and used by the Department must be served on the State Attorney and the relevant Accounting Officer in the national or provincial department;

2 in terms of the 9 October 2009 order, the relevant treasury has to cause the judgment debt to be settled, settle the debt itself or make arrangements in this regard. In the 31 August 2009 order, the party was not specified;

3 the 9 October 2009 order specified that the property must be owned by the State and used by the relevant department;

4 the 31 August 2009 order did not specify that the property may not be removed when attachment has taken place;

5 in terms of the 9 October 2009 order, a stay of execution may be applied for by a party having a direct and material interest (as opposed to any affected party (see the 31 August 2009 order));

6 in terms of the 9 October 2009 order, a stay of execution may be applied for during the period relating to the removal and sale in execution of the property. In terms of the 31 August 2009 order, a stay of execution may be applied for during the period relating to (a) the application for a writ of execution or (b) the sale in execution of the attached movable property;

7 in terms of the 9 October 2009 order, a stay of execution may be applied for on the ground that execution is not in the interests of judgment. In terms of the 31 August 2009 order, a stay of execution may be applied for on the ground that it is not in the interests of justice and good governance; and

8 only the 31 August 2009 order made provision for the duty on a specific party to establish that it would not be in interests of justice and good governance for the State property to be sold.

THE 2011 STATE LIABILITY AMENDMENT BILL [B 2B-2011]

As indicated above, ${ }^{119}$ the $\mathrm{CC}$ in the $2010 \mathrm{CC}$ case extended the period of suspension of invalidity from the initial 31 August 2009 to 31 August 2011. This implied that the necessary national legislation that would give effect to the decision in the 2008 CC case had to be enacted, assented to and commence by not later than 31 August 2011. Within this context, the State Liability Amendment Bill, 2011 [B 2-2011] was introduced to the Portfolio Committee concerned (the National Assembly) on 4 February $2011 .{ }^{120}$

\footnotetext{
119 Par 97 above.

120 http://www.pmg.org.za/billsstatus/proceedings. According to the Memorandum on the Objects of the State Liability Amendment Bill, 2011 par 3.2, the comments received in
} 
Various submissions were received by the Portfolio Committee on Justice and Constitutional Development regarding the State Liability Amendment Bill, 2011 [B2-2011] during its public hearings. The Cape Bar Council, Deneys Reitz Attorneys, the Department of the Premier: Western Cape, Eskom, the FW de Klerk Foundation: Centre for Constitutional Rights, Idasa, the Law Society of South Africa, Section 27: Catalysts for Social Justice, and Standard Bank made a range of inputs, ${ }^{121}$ which, amongst others, resulted in a number of amendments to the 2011 Bill as introduced, and the finalization of the amended version, [B 2B-2011] (hereinafter the "2011 Bill").

The Portfolio Committee Report was completed on 2 June 2011, and the National Assembly considered the 2011 Bill on 8 June 2011. It was referred to the Select Committee on Security and Constitutional Development, which reported on 22 June 2011 that it had agreed to the 2011 Bill without amendments. The 2011 Bill was then considered and passed by the NCOP on 4 August 2011.

The long title of the State Liability Amendment Bill [B 2B-2011] indicates that its aim is to amend the Act ${ }^{123}$ "so as to regulate the manner in which a final court order sounding in money against the State must be satisfied". Section 3 of the Act is replaced by a comprehensive framework, ${ }^{124}$ which provides for a step-by-step process for the payment of a final court order against the State sounding in money, and if payment is not effected, the attachment and sale in execution of movable property belonging to the department concerned. The executive authority of the department concerned must be cited as nominal defendant or respondent (and copy must be served on State Attorney). ${ }^{125}$ Based on the Memorandum on the Objects of the State Liability Amendment Bill, 2011, the process for the satisfaction of a final court order sounding in money consists of the following main elements: ${ }^{126}$

1 No execution, attachment or similar process in respect of movable property of the State may be issued and effected if no payment has been received after full compliance with the prescribed procedure for the satisfaction of a final court order sounding in money.

2 The State Attorney or attorney of record representing the department concerned must within 7 days of the final court order sounding in money inform both the executive authority and accounting officer of the

respect of the State Liability Bill, 2009 (see discussion above (par 7)) "were accommodated, where appropriate".

121 http://www.pmg.org.za/report/20110309-state-liability-amendment-bill-public-hearings. See also http://www.pmg.org.za/report/20110622-committee-deliberations-state-liability-amend ment-bill-b2b-2011 (Clause by Clause Summary of Submissions: State Liability Amendment Bill, 2011 [B2-2011]).

122 http://www.pmg.org.za/billsstatus/proceedings.

${ }^{123}$ State Liability Act 20 of 1957.

${ }^{124}$ Clause 2.

125 Clause 1.

${ }^{126}$ Clause 2, as well as the Memorandum on the Objects of the State Liability Amendment Bill, 2011 par 2.2 (especially with reference to clause 2 ).

127 Clause 2(1). 
department concerned, as well as the national or provincial treasury (as the case may be). ${ }^{128}$

3 Such final court order must be satisfied within 30 days or within a time period as agreed upon between the judgment creditor and the accounting officer concerned. Payment must be effected against the budget of the department, as appropriated by the legislature concerned. ${ }^{12}$

4 In the case of non-payment by the department concerned (as envisaged in 3 above), the judgment creditor may serve the final court order in the prescribed manner (the applicable Rules of Court) on the following persons: the department's executive authority and accounting officer, the State Attorney or attorney of record, and the national or provincial treasury (as the case may be). ${ }^{130}$

5 The national or provincial treasury (as the case may be) must, within the period of 40 days of service of the final court order (as envisaged in 4 above), take the necessary steps for the payment of the judgment concerned or within a time period as agreed upon between the judgment creditor and the treasury concerned.

6 In the case of non-payment by the treasury concerned (as envisaged in 5 above), the judgment creditor may request in writing the issuing of a writ or warrant of execution against movable property, which is owned by the State and is utilised by the department concerned.

7 After the issuing of the writ or warrant of execution (as envisaged in 6 above), the sheriff of the court concerned must attach (but not remove) any movable property. However, if an agreement is reached between the sheriff and a designated departmental official that specific movable property should not be attached, removed and sold in execution on account of the ensuing disruption of service delivery, the threatening of life or putting the security of the public at risk, other movable property may be attached.

8 After a period of 30 days from the date of attachment, the sheriff may remove and sell the movable property attached as contemplated in 6 above.

9 The relevant Rules of Court apply to the process of issuing of the writ or warrant of execution, the attachment, and the subsequent removal and sale in execution. ${ }^{135}$

10 Before removal and sale in execution (as envisaged in 8 above), an application may be made for a stay of execution by any party having a direct or material interest to the court which has granted the final order (on the basis that such execution would result in the disruption of service

${ }^{128}$ Clause 2(2).

${ }^{129}$ Clause 2(3).

130 Clause 2(4).

131 Clause 2(5).

132 Clause 2(6).

${ }^{133}$ Clause 2(7).

134 Clause 2(8).

135 Clause 2(9). 
delivery, the threatening of life or putting the security of the public at risk). Other movable property (available for attachment, removal and sale in execution) and its location must be identified in the application (notice of which must also be given to the judgment creditor and the sheriff). ${ }^{136}$

11 The national or provincial treasury (as the case may be) may "make or issue appropriate regulations, instructions, circulars, guidelines and reporting rules", 137 withhold sufficient funds voted for a specific department to ensure payment of an outstanding final court order, and pay an outstanding final court order on behalf of the department concerned (and concomitantly debit the department's budget). ${ }^{13}$

12 If the appropriated funds for the department concerned were to be insufficient for the payment of the final court order, the national or provincial treasury (as the case may be) is empowered to extend (a) the withholding of funds from the department concerned, or (b) the payment of the outstanding final court order, for a period longer than one financial year. ${ }^{139}$

13 Payment of an outstanding final court order by the national or provincial treasury (as the case may be) is regarded as satisfaction by the department concerned (and not by the treasury concerned). In addition, the accounting officer retains full responsibility, accountability and liability as contemplated in the PFMA - also in respect of financial misconduct as provided for in clause 16 of the 2011 Bill (see below). ${ }^{140}$

14 Any payment by the accounting officer (including payment by the national or provincial treasury (as the case may be) on behalf of the accounting officer concerned) of a final court order must be effected in full compliance with the PFMA, as well as with any regulations, instructions, circulars, guidelines and reporting rules issued by the national or provincial treasury (as the case may be). ${ }^{141}$

15 The accounting officer of every national and provincial government department must put in place appropriate budget procedures for the timeous payment of final court orders. These procedures must comply fully with any regulations, instructions, circulars, guidelines and reporting rules issued by the national or provincial treasury (as the case may be). ${ }^{142}$

16 The failure of any accounting officer to comply with and adhere to the provisions of clause 3 or any regulation, instruction, circular, guideline and reporting rule issued by the national or provincial treasury (as the case may be) constitutes financial misconduct as contemplated in the PFMA, and such accounting officer is guilty on conviction of an offence as provided for in the PFMA. In addition, the accounting officer is

${ }^{36}$ Clause 2(10).

${ }^{37}$ The Memorandum on the Objects of the State Liability Bill, 2011, par 2.2.2(I).

${ }^{138}$ Clause 2(11).

${ }^{139}$ Clause 2(12).

${ }^{140}$ Clause 2(13).

141 Clause 2(14).

${ }^{142}$ Clause 2(15). 
explicitly prohibited from assigning to any other departmental official, his or her duty "to ensure the timeous satisfaction of final court orders". ${ }^{14}$

Clause 3 (insertion of a new section 4A in the Act) consists of definitions, and clause 4 provides a framework for the management of transitional measures relating to those final court orders sounding in money which were made prior to the commencement of the 2011 Bill and which have not been paid within 30 days after said commencement.

\section{CONCLUDING REMARKS AND RECOMMENDATIONS}

With regard the $2010 \mathrm{CC}$ case, the period of suspension of invalidity was extended to 31 August 2009, and later to 31 August 2011.

The 2011 Bill in its final form will in all probability be assented to by the President and the commencement date fixed on a date not later than 31 August 2011 (as required by the 2010 CC case). The enactment of the 2011 Bill gives a clear indication of the intention of both the Executive and the National Legislature to comply fully with the Constitution and to protect the role and inherent powers of the Judiciary to protect and regulate its own judicial process (as explicitly provided for in section 173 of the Constitution).

Matters that still need to be addressed in order to bring about a comprehensive and all-encompassing framework for the proper, efficient and effective management of successful claims lodged against the State include, amongst others, the extension of the 2011 process to the municipal sphere of government and all organs of state (whether they are public entities or not). Furthermore, unlike the 2009 Bill, the 2011 Bill does not provide for interim payments in the case of relief for "urgent or necessary medical treatment". ${ }^{144}$ (This should in actual fact be extended to also include other urgent circumstances to be determined in the discretion of the court concerned, such as maintenance for minor children in the case of a deceased or injured breadwinner.) In addition, the current limitation as regards the attachment and sale in execution of only movables which are the property of the State, may in a given context, for example, where the movable assets of a small government department or the withholding of (a part of) its appropriated budgets over a number of years is insufficient to satisfy the final court order, result in effective non-compliance or only partial compliance with the court order concerned. (This will especially be the case when the current legislation is expanded to include resource-poor municipalities and organs of state with limited movable assets.) This proposed expanded framework will ensure the expedited provision of full justice to successful claimants.

${ }^{143}$ Clause 2(16), as well as the Memorandum on the Objects of the State Liability Bill, 2011, par 2.2.2(q).

${ }^{144}$ See clause $7(2)$ of the 2009 Bill, and par 7 above. 